\title{
Recent changes to EU law on GMOs and their potential influence on the patentability of GM plants. Some remarks on possible side effects of Directive 2015/412/EU
}

\author{
TOMASZ ZIMNY \\ Institute of Law Studies, Polish Academy of Sciences, Warszawa, Poland
}

\begin{abstract}
In this article I present recent changes in EU legislation on the cultivation of GM plants and I attempt to answer the question as to whether the new laws continue to follow the precautionary principle approach and the case by case approach that characterized the European Union's GMO legislation until recently. Also, given the nature of the newly introduced grounds for restricting the cultivation of GMOs, I try to find out if the new legislation could influence the patentability of transgenic plants or methods of their production. While growing in popularity around the world, transgenic plants face strong opposition within the European Union. Recent changes to EU legislation governing the cultivation of GM plants are just another example of the said opposition. Directive (EU) 2015/412 of the European Parliament and of the Council amending Directive 2001/18/EC provided member states with means to restrict or effectively prohibit cultivation of genetically engineered plants in their territories, even if such plants have already been authorized for cultivation in the EU. The reasons countries can currently invoke in order to introduce limitations are no longer restricted to bio-safety, but rather encompass a set of political and social issues such as socioeconomic impacts, avoidance of GMO presence in other products, agricultural policy objectives, public policy etc. They are to a much lesser extent (than up till now) based on the precautionary principle, as possible restrictions will also concern already examined and authorized GMOs. Restrictions no longer need to target particular transformation events, they can now encompass certain traits or crops. When it comes to the patentability of GM plants or methods of their production, the recent changes seem to have limited influence, given the European Patent Office's stance on the application of morality and “ordre public" exclusions and its relative independence from EU law. The possibility cannot be excluded that local laws adopted on the basis of the newly introduced changes could influence procedures before local patent office, should those offices decide to apply the morality or "ordre public" exception to patentability. The newly adopted laws have a rather different effect, though. The profitability of developing GM plants in the EU (and their patenting) may become questionable, should the exploitation of such inventions be prohibited in several EU member states.
\end{abstract}

Key words: GMO, european law, precautionary principle, patent law, patentability

\section{Introduction}

The European Union has some of the strictest laws regulating the use of genetically modified organisms ( $\mathrm{Da}-$ vidson, 2010). Nearly every activity involving such organisms - from research to marketing and post marketing monitoring - is regulated by EU legislation. Stringent regulations apply in particular to placing genetically engineered products on the market, not only as food or feed but also as sowing material. Under the European Union's regulations, planting a GM crop is only allowed if that particular crop has passed a thorough risk assessment procedure and has been approved for cultivation by either a competent authority in one of the member states or by the Commission of the European Union. So far, only MON 810 corn has been approved for cultivation and this is grown in Spain, Portugal, the Czech Republic, Romania and Slovakia (James, 2015).

This article presents recent changes to EU legislation on the cultivation of GM plants and compares them to previous rules, in order to test a hypothesis that the recently introduced changes constitute a departure from the precautionary and case by case approaches that have thus far been fundamental. The article also examines whether the new legislation could influence the patentability of GM plants, given that the new reasons for restricting the use of GMOs are based on political and 
axiological concerns, which also constitute reasons for excluding the patentability of certain inventions. Both issues are examined via a comparison of various legal acts and also an interpretation of provisions in the context of past and current case law.

Use of GM plants in agriculture is regulated by $D i$ rective 2001/18/EC of the European Parliament and of the Council of 12 March 2001 on the deliberate release into the environment of genetically modified organisms and repealing Council Directive 90/220/EEC ("Directive 2001/18/EC"). The objective of the Directive is, "in accordance with the precautionary principle, to approximate laws in the area as well as the laws, regulations and administrative provisions of the member states, and to protect human health and the environment when (...) placing on the market genetically modified organisms as or in products within the (Union)". The directive mandates that member states adopt legislation providing that any person planning either to deliberately release GMOs into the environment for experimental purposes or to market them as products, does so only after performing proper risk assessment and obtaining authorization from competent authorities. There is a zero tolerance threshold for placing on the market GMOs that have not been authorized for marketing according to EU law (see, the European Court of Justice Judgment in case C-442/09).

The legislation (at least until quite recently - see below) was based on the precautionary principle (PP), which is a procedural (decision making) rule used in risk management and risk analysis. The principle mandates that decision makers should undertake risk limiting measures "where scientific evidence is insufficient, inconclusive or uncertain and there are indications through a preliminary objective scientific evaluation that there are reasonable grounds for concern that the potentially dangerous effects on the environment, human, animal or plant health may be inconsistent with the chosen level of protection" (COM 2000 (1)). The measures taken have to be proportional to the chosen level of protection, non-discriminatory in their application, consistent with similar measures already taken, based on an examination of the potential benefits and costs of action or lack of action, subject to review in the light of new scientific data, and capable of assigning responsibility for producing the scientific evidence necessary for a more comprehensive risk assessment (COM 2000 (1)). In the legislation concerning the use of GMOs, $\mathrm{PP}$ is ma- nifested in the requirement that all GMOs planned for marketing should be thoroughly examined and undergo risk assessment before they reach the common market. Only if the effects of the said assessment are favorable (i.e. cultivation and consumption do not pose any threats to human or animal health or to the environment) can a particular GMO be authorized for marketing. While criticized at times for its low cost effectiveness and vagueness (Jansen van Rijssen, Eloff, Morris, 2015), PP constitutes the cornerstone of the EU's approach to GMOs.

Another important principle strongly connected to $\mathrm{PP}$ is one that mandates acting according to a case by case approach. According to this principle, all GMOs (all transformation events) should be treated individually, so that no general conclusions are drawn as to their safety as products. Consequently, for instance, the case by case approach does not permit the assumption in the decision making process that GM plants are generally safe for consumers or that they are harmful, based solely on experiences with different GMOs. the potential effects of growing e.g. herbicide resistant corn and Bt corn may differ. Such effects depend on a plethora of factors: the function of the insert, the species, its ability to reproduce and survive in the environment, the vector used etc. The presented approach does not allow the formulation of general conclusions about the safety of broad groups of organisms (e.g. all GMOs, GMOs of a particular species or GMOs possessing a particular trait). The application of both PP and the case by case approach bears significant costs.

$\mathrm{PP}$ is designed for decision making in situations of significant scientific uncertainty. Its application is costly and requires measures, which may prove unnecessary (Gadomski and Zimny, 2009). Also, the cost of delaying an action because of the precautionary principle, and hence losing benefits that may possibly stem from the said action, has to be factored into the general costs of PP application (Cantley, 2012). The scope of PP application should be limited to situations where there is not enough scientific data to support a claim that a certain action is either safe or too risky. In such cases, other risk management strategies should be applied.

Therefore until recently, after a particular GMO had been approved for marketing in the European Union, member states were not allowed to introduce restrictions on products containing that GMO or the GMO itself. According to art. 22 of Directive 2001/18/EC, 
"Member States may not prohibit, restrict or impede the placing on the market of GMOs, as or in products, which comply with the requirements of this Directive". However, the next article of the same Directive contains a safeguard clause, according to which member states can provisionally restrict or prohibit the use or sale of such authorized GMOs as or in a product on their territories. There are several conditions that have to be met in order to impose such restrictions legally. Firstly, they have to target particular GMOs, so the safeguard clause cannot be invoked in order to restrict the use of GMOs in general or those belonging to a particular species, etc. Secondly, the safeguard clause may only be invoked when there are reasons to believe that a previously authorized GMO constitutes a risk to human health or the environment. This belief has to be based on detailed grounds stemming from new or additional information made available after the date of the authorization or from reassessment of the existing information on the basis of new or additional scientific knowledge. Restrictive measures should thus be based on some new scientific information, according to which the risk assessment that was carried out before the authorization, did not reveal potential threats connected with the use of the authorized GMO. It is a duty of the member states to introduce and enforce efficient laws with the aim of preventing serious harm to the environment (Nanda et al., 2013). Political or social reasons, such as public aversion towards GMOs, political statements declaring countries or their parts "GMO free", cannot constitute grounds for applying the safeguard clause from art. 23 of $\mathrm{Di}$ rective 2001/18/EC, or adopting restrictive measures. However, the above clause has been invoked in the past by several countries aiming to restrict the use of some GMO products in their territory, contrary to the scientific opinions of such bodies as the European Food Safety Authority (EFSA) or their local scientific committees (Davidson 2010$)^{1}$. On some occasions, certain restrictive

\footnotetext{
${ }^{1}$ It is clear that the safeguard clause - initially designed to protect consumer health in urgent cases - has been used as a means to eliminate GM plants from particular countries' agriculture. It was an efficient method, given the limited number of transgenic plants approved for cultivation (practically only one). Some countries resorted to slightly different methods. A notable example of this is the Polish Council of Ministers' Regulation on the prohibition of use of the sowing material of MON 810 corn varieties, which prohibits cultivation of over $200 \mathrm{MON} 810$ varieties. The regulation is based on a provi sion of the Act on seed production. Allegedly based on some safety
}

measures were subsequently approved by the Council. Pursuant to directives regulating plant breeding, it is also possible to restrict the use of seeds of particular varieties. In spite of this fact, until recently, member states had limited possibilities to impose restrictions on already authorized GM products. This situation has changed significantly after the adoption of Directive 2015/412/EC, which added some crucial provisions to Directive 2001/18/EC.

\section{Recent changes in EU laws on the cultivation of GM plants ${ }^{2}$}

Following the Commission's recommendation of 2010 (Recommendation on the guidelines for the development of national co-existence measures to avoid the unintended presence of GMOS in conventional and organic crops), which proposed the introduction of the possibility for member states to opt out of the cultivation of GM crops, the European Parliament and Council adopted Directive 2015/412/EC, amending Directive 2001/ $18 / E C$ as regards the possibility for the Member States to restrict or prohibit the cultivation of genetically modified organisms (GMOs) in their territory. Firstly, the Directive imposes a new obligation on those member states where GMOs are grown. As from 3 of April 2017, those states "shall take appropriate measures in border areas of their territory with the aim of avoiding possible cross-border contamination into neighboring Member States in which the cultivation of those GMOs is prohibited, unless such measures are unnecessary in the light of particular geographical conditions". This provision could be of significance for the Polish case, since the cul-

concerns, this regulation leads to a paradox, where it is legal to use MON 810 corn as food, feed or even to sell its sowing material, but it is illegal to grow it. It may be that the reason for the adoption of Directive 2015/412/EC was to allow member states to effectively remove GM plants from their landscapes, without them having to resort to such convoluted schemes as that presented above.

${ }^{2}$ It is worth mentioning that the Polish Law on GMOs also underwent important changes in early 2015, with the adoption of an act introducing serious changes to the existing regulations (Dz. U. 2015.277). Important as they may be, the changes mostly affect contained use of GMOs and GMMs (where the changes liberalize the administrative procedures somewhat, yet not to the extent that is permitted in EU law) and deliberate release for experimental purposes. New changes to Polish law have been based on earlier EU legislation and do not have EU-wide effect and mostly affect the scientific community. Therefore, they fall outside the scope of this article and have been, as such, deliberately omitted. 
tivation of MON 810 is currently prohibited in Poland, while two of the countries where the corn is currently grown in the EU (Slovakia and the Czech Republic) border Poland. The provision may be of lower significance in this case, since the border passes mostly through mountainous areas, limiting the possibility of pollen flow or other forms of trans-border movement. Were some GM plants grown in eastern Germany for instance, the importance of the cited provision could rise.

The most striking change introduced in Directive $2015 / 412 / \mathrm{EC}$ is the one allowing member states to restrict the use of GMOs in their territory for reasons other than those connected with human, animal or environmental safety. According to the newly introduced article $26 \mathrm{~b}$, even before a new GMO has been authorized for marketing (during the authorization procedure) or when an authorization is renewed, a member state may demand that the geographical scope of authorization or consent be so adjusted that the territory of that member state or its part are excluded from that authorization. This restriction can apply not only to the consent for cultivation, but also to decisions authorizing GMOs as food or feed (art. 26b of Directive 2001/18/EC). Effectively, this means that even before the GMO is authorized, member states can opt out from its use in their territory.

Even if a member state did not request a geographical restriction initially, it is still entitled to introduce restrictive measures (be it because of a change in the government or a change of local policies etc.). The adopted measures can mean the restriction or even prohibition of cultivation in all or part of the territory of the member state. Restrictions can target not only particular GMOs but also groups of them, defined by crop or trait (e.g. "transgenic corn", "GMOs with herbicide resistance" and combinations thereof). Such restrictions have to conform with European Union law, and be reasoned, proportional and non-discriminatory (for instance, they cannot target GMOs basing on their country of origin or a manufacturer). A country aiming to introduce such post-authorization restrictions has to base them on one or more of the following reasons:

a) environmental policy objectives;

b) town and country planning;

c) land use;

d) socioeconomic impact;

e) avoidance of GMO presence in other products (...); f) agricultural policy objectives;

g) public policy.

The above grounds can be invoked individually or in combinations, with the exception of "public policy", which cannot be invoked individually. Invoked grounds cannot conflict with the environmental risk assessment carried out in order to authorize the GMO as food, feed or sowing material. This means that states wanting to introduce bans on GMOs cannot simply claim that they have reservations as to the safety of their use, without having scientific reasons for it. Should they have such reasons based on scientific knowledge, they ought to apply the safety clause as mentioned earlier. This limitation of the possibility to introduce a restriction or prohibition may prove to be purely hypothetical, as most of the grounds countries can invoke are detached from issues of biosafety, which are addressed in the risk assessment procedure. While some environmental safety concerns can be deduced from the first prerequisite (environmental policy objectives), they are not necessarily present in several others, such as socioeconomic impact, land use or public policies. The Commission can comment on proposed measures; its comments are nonbinding, however.

The newly adopted legislation constitutes a radical departure from the major principles that constituted the basis of the previous legal order. While the authors of the new directive seem to have invoked the Precautionary Principle as one of the grounds for its adoption (see Recital 2 of Directive 2015/412/EC), it is quite difficult to view new provisions as being particularly representative of the said principle. PP justifies application of restrictive measures if accessible scientific data do not suffice to rule out or at least efficiently manage the apparent risks connected with some action, be it growing GMOs or any other. Meanwhile, new provisions allow countries to prohibit cultivation of some GMOs even though those GMOs have passed the risk assessment procedure. A prohibition based on reasons unconnected with biological safety issues or on reasons that seem to be of ideological nature cannot be seen as an example of applying the Precautionary Principle. Irrespective of the fact that PP was differently defined in the past (see COMEST 2005, p. 13), there are some common elements of its application, including: scientific analysis, and the existence of considerable scientific uncertainties as to causality, magnitude, probability and the nature of 
harm. The interventions should be proportional to the chosen level of protection and the magnitude of a possible harm (COMEST 2005 p. 13-14).

Even if we were to assume that the new legislation aims at constraining or containing possible harm stemming from the mere fact that transgenic plants are grown in a particular member state and even if we were to assume that that possible harm may occur in spheres other than biological safety (e.g. local economy, spatial planning etc.), it is still quite difficult to view the new restrictions as an application of PP. Not only is the plausibility of the occurrence of such harm not too well assessable, but also such harm is difficult to define when it comes to its magnitude and extent. Hence, it is also dubious that such measures are proportional to the possible harm.

Another significant change brought about by the new legislation is a serious limitation of the case by case principle. Unlike in the case of the safety clause, where restrictive measures are supposed to target particular GMOs, restrictions adopted according to the new laws can apply to broader groups of transgenic organisms. According to new art. 26b par. 3 of Directive 2001/18/WE, "a Member State may adopt measures restricting or prohibiting the cultivation in all or part of its territory of a GMO, or of a group of GMOs defined by crop or trait". An application of the case by case principle in decision making about the marketability of GMOs is justified by the nature of genetic modification. Since there are multiple ways of modifying multiple features of an organism, there are also multiple issues to be addressed when it comes to risks connected with those procedures. "The objective of an environmental risk assessment is, on a case by case basis, to identify and evaluate potential adverse effects of the GMO, direct and indirect, immediate or delayed, on human health and the environment which the deliberate release or the placing on the market of GMOs may have. The environmental risk assessment should be conducted with a view to identifying if there is a need for risk management and if so, the most appropriate methods to be used." (Directive 2001/18/EC Annex II p. A) In order to achieve that goal (a) risk assessment has to be carried out on a case by case basis, in a scientifically sound and transparent manner based on available scientific and technical data. The identified characteristics of the GMO and its use which have the potential to cause adverse effects should be compared to those presented by the non-modified organism from which it is derived and to its use under corresponding situations (Directive 2001/18/EC Annex II p. A and B). Amongst the traits tested in higher plants, these include the likelihood for the GMO to become persistent and invasive, the potential for gene transfer to other species, potential environmental impacts on target and non-target organisms, etc. The features of the insert and vector are also taken into account (Directive 2001/18/EC Annex II, III). Identification of these traits can constitute a basis for deciding whether a particular organism is safe to be released into the environment or not. All the above mentioned factors justify the case by case approach, since a change in one of them can have serious safety consequences.

The newly adopted rules allow individual traits of GMOs in question to be completely disregarded, as the restrictions may apply to whole groups of organisms, defined solely by their trait or crop. This means that member states can introduce restrictions on the cultivation of e.g. transgenic corn, Bt corn, etc. This fact, combined with the recently adopted grounds for justifying the restrictions that are, for the large part, not connected to biological or environmental safety issues, marks a radical change in the EU's approach to GMOs.

The obstacles to placing such organisms on the market, which were amongst the largest in the world (Davidson, 2010), have now become even more daunting. This may impact not only upon entrepreneurs interested in marketing GM plants in the EU, but also upon farmers and scientists. It is, however, too early to estimate the extent and seriousness of these impacts. There is a group of possible impacts that seem less obvious, though. They pertain to the influence of the recent changes on the patentability of GM plants.

\section{Possible impacts on the patentability of GM plants}

Despite a lengthy and vigorous debate about the patentability ${ }^{3}$ of GM plants or the patentability of living organisms in general (see Crespi, 2000), genetically modified plants and processes of their making are currently pa-

\footnotetext{
${ }^{3}$ Patentability can be defined as a set of features, such as novelty, inventive step and industrial applicability, which an invention has to possess to be protected by a patent. There are also factors limiting patentability, in particular those connected with the moral and legal aspects of the exploitation of an invention.
} 
tentable. According to art. 3 of Directive 98/44/EC on the legal protection of biotechnological inventions (henceforth Directive 98/44/EC), "inventions which are new, which involve an inventive step and which are susceptible of industrial application shall be patentable even if they concern a product consisting of or containing biological material or a process by means of which biological material is produced, processed or used". Also, "biological material which is isolated from its natural environment or produced by means of a technical process may be the subject of an invention even if it previously occurred in nature". According to art. 4 par. 1 let. a, plant and animal varieties are excluded from patentability; however, this exclusion does not preclude patenting of transgenic plants in general (Stercx and Cockbain, 2012). As stated in Recital 31 to Directive 98/44/EC, "a plant grouping which is characterized by a particular gene (and not its whole genome) is not covered by the protection of new varieties and is therefore not excluded from patentability even if it comprises new varieties of plants". Hence, it is possible to patent e.g. a transgenic, herbicide resistant corn, where the resistance is conferred by a particular introduced gene or set of genes, so long as the patent claims do not refer to a particular variety of that corn. This issue is currently considered rather controversial in the doctrine (see Sterckx and Cockbain 2012 p. 193242).

There are other reasons for excluding the patentability of certain inventions, namely those, whose commercial exploitation would be contrary to morality or "ordre public". This exclusion was introduced in art. 6 par. 1 of Directive $98 / 44 / \mathrm{EC}$, but it was in one way or another a part of the patent law even before the adoption of that directive. In particular, according to art. 53 (a) of the European Patent Convention (henceforth EPC), "inventions, the commercial exploitation of which would be contrary to "ordre public" or morality; such exploitation shall not be deemed to be so contrary merely because it is prohibited by law or regulation in some or all of the Contracting States". Such exclusions are also present in Polish patent law (see art. 29 par. 1 pt. 1 and art. $93^{3}$ of Industrial Property Law of 2000). Since its inclusion in the patent law, this exclusion from patentability has been used rather rarely. Its "renaissance" began with the advent of biotechnological inventions. One of the reasons for this was the fact that such inventions often touch spheres that are of particular importance, such as environmental safety, human dignity, autonomy etc. Another reason for the increased importance of the "morality exclusion" was that various groups that opposed the granting of patents on living organisms and biotechnological inventions in general, invoked this exclusion in order to prevent the granting of such patents. One of the more significant cases brought before the Technical Board of Appeal of the European Patent Office (henceforth EPO) was Case T 356/93 (Plant cells), where the applicant sought to receive a patent for herbicide resistant plants, cells of such plants and methods of their production. An opposition against the granting of said patent was filed by Greenpeace Ltd. on, among others, the grounds that the granting of a patent for plant life forms and the exploitation of the patent was contrary to morality or "ordre public" (Decision T 356/93 par. II). Not only was the mere fact that plants are patented questioned on moral grounds, but also safety concerns connected with the possible effect of such plants' release into the environment were raised. The Technical Board of Appeal was tasked with defining the terms "morality" and "ordre public" for the purposes of patent law, as well as with deciding whether moral or legal reasons justified revocation of the granted patent. In its decision, the board stated that "the concept of morality is related to the belief that some behavior is right and acceptable whereas other behavior is wrong, this belief being founded on the totality of the accepted norms which are deeply rooted in a particular culture. For the purposes of the EPC, the culture in question is the culture inherent in European society and civilization. Accordingly, under Article 53(a) EPC, inventions the exploitation of which is not in conformity with the conventionally-accepted standards of conduct pertaining to this culture are to be excluded from patentability as being contrary to morality". Also, the board decided to define the concept of "ordre public", by stating that it "covers the protection of public security and the physical integrity of individuals as part of society. This concept encompasses the protection of the environment as well. Accordingly, under Article 53(a) EPC, inventions the exploitation of which is likely to breach public peace or social order (for example, through acts of terrorism) or to seriously prejudice the environment are to be excluded from patentability as being contrary to "ordre public".

Setting aside several problems inherent in these definitions, in particular the rather blurry concept of "cul- 
ture inherent in European society and civilization", as a basis for the formation of moral norms according to which the inventions should be measured or the concept of one public order in all contracting states (Hansen, 2002), the presented definitions indicate some important areas where the patentability of transgenic plants could be questioned. Chiefly, inventions whose exploitation would seriously endanger the environment would be considered not patentable on the grounds of their exploitation being contrary to the "ordre public". While the exploitation of an invention can only be considered as offending the "ordre public", if it is already prohibited by law (Schatz, 2000). This is the case when it comes to most GM plants, because their patentability is usually examined before they are authorized for marketing. It should also be noted that the exploitation of an invention that is harmful to the environment would also most likely be deemed contrary to morality. The question remains, however, if the patent office should assume that a yet unauthorized GM plant threatens the environment, or should such an office give the plant the benefit of the doubt. The EPO Technical Board of Appeals settled for the latter option. In the already cited decision, T 356/93/EC, the board stated that "it would be unjustified to deny a patent under Article 53(a) EPC merely on the basis of possible, not yet conclusively-documented hazards (...) Should the competent authorities and bodies, after having definitively assessed the risks involved, prohibit the exploitation of the invention, the patented subject-matter could not be exploited anyhow. If, however, regulatory approval is given based on the finding that no risks or minimal risks are involved, then patent protection should be available". As was further stressed, patents should not be granted for inventions that would relate to misuse or a destructive use of plant biotechnology (T 356/93, p. 17.1). Examples of these would include plants specially designed to cause harmful effects, plants used as biological weapons etc. This is not the case in respect to most, if not all currently developed transgenic plants that are being patented with the intention of their subsequent marketing. Since the purpose of their development is to improve some agronomical, dietary or other trait, it is the risks connected with their exploitation that could bar the possibility of patenting, not their purpose or the method by which they were created (genetic modification). In order to deny or revoke a patent, the patent office should be presented with reliable information that the exploitation of that particular invention would seriously prejudice the environment. As the board stated, "the revocation of a European patent under Article 53(a) EPC on the grounds that the exploitation of the invention for which the patent has been granted would seriously prejudice the environment presupposes that the threat to the environment be sufficiently substantiated at the time the decision to revoke the patent is taken by the EPO" (T 356/93, p. 18.5). This stance was also maintained in other cases brought before the EPO Technical Board of Appeals (see e.g. case T 179/01 par. 7) Hence, in the case of patenting transgenic plants the situation seems quite different than in the case of their authorization for marketing. In the latter case, it is impossible to obtain an authorization until the plant in question is proven to be safe. In the case of their patentability, a patent can be denied or revoked on the basis of morality or "ordre public", if the patent office decides that it was sufficiently proven that the invention in question will seriously harm the environment or pose other kinds of threats. This approach seems reasonable, since denying patents on the basis of some general presumptions or hypothetical threats could practically preclude patenting not only transgenic organisms but also medicines and other products that require some form of authorization before they are placed on the market.

The newly adopted laws regarding the cultivation of GM plants may raise questions as to their influence on their patentability. As mentioned earlier, the new reasons for restricting cultivation often have little to do with biological safety issues. Rather, they address other types of concerns, such as the possible influence of GM crop cultivation on the local social or economic situation, the relation of such cultivation to however defined agricultural policy objectives, town and country planning etc. These are issues of some moral importance. A question thus arises as to whether a patent office could deny a patent on the grounds of morality or "ordre public", based on the fact that local policies prohibit the use of GMOs belonging to the species of the patented invention, or laws prohibiting the use of GMOs possessing a trait that is also characteristic for the patented invention (viz. a transgenic plant). It seems that this would be quite unlikely in the case of proceedings before the European Patent Office. Firstly, as has already been mentioned, article 53 (a) of the EPC states that the of- 
fice cannot simply deem exploitation of an invention contrary to morality or the "ordre public", based merely on the fact that such exploitation is prohibited by law or by a regulation in some or all of the contracting states. One could argue that any inconsistency with morality may lie deeper and not follow simply from the fact that an antiGMO policy was adopted in a particular state, but from the fact that this policy protects some important values. It would then be those values which had been threatened by the exploitation of the invention. In such a case, the denial or revocation of a patent could be justified not by a mere contradiction to local laws, but by the influence of the invention on some spheres of human activity that are particularly valued. Such argumentation would not hold either, and there are several reasons for this.

Firstly, the European Patent Convention is a standalone international agreement and, despite the fact that all the members of the EU are parties to the convention, it itself is not a part of EU law. There are currently 38 members of the European Patent Organization, only 28 of them are members of the EU. Thus, the EPO is not an institution of the EU and is not bound by its laws. There is some form of indirect influence of both legal orders, e.g. the substantial provisions of Directive 98/44/ $\mathrm{EC}$ have been added to the Implementing Regulations of the European Patent Convention in order to harmonize it with laws adopted in EU member states. The European Patent Office, not being an EU institution, is not accountable to any judicial body of that organization, including the European Court of Justice ${ }^{4}$ and has re

\footnotetext{
${ }^{4}$ This does not mean that the European Court of Justice (ECJ) does not influence patent law at all. Several of its judgments touch upon the subject. Notable examples include: case C-377/98, where the court decided that Directive $98 / 44 / \mathrm{EC}$ was in conformity with EU law or case C-34/10, where the court, on moral and "ordre public" grounds, excluded the patentability of certain types of human embryonic stem cells and methods of their procurement and also defined the term "human embryo" for the purposes of patent law. Another example is case $\mathrm{C}-428 / 08$, where the ECJ ruled that a patent protecting a DNA sequence is extended to biological material in which the genetic information is contained and performs its function (e.g. sowing material). This protection does not cover products, where the patented sequence does not perform its function anymore, for example soy meal. In the discussed judgment a so-called "absolute protection" of DNA sequences was also ruled out. Important as they might be, the presented judgments are of limited significance from the point of view of the goals of this article. In particular, case C-34/10 tackles the issues of morality and "ordre public" as grounds for excluding patentability of inventions, but it does so in the field of bio-medical research, where human biological material is used. Case C-428/08 applies to patenting GM plants and DNA sequences di-
}

fused to refer legal questions to that court in the past (see e.g. Decision G 2/06). A change in EU laws concerning member states' ability to prohibit the cultivation of some GM crops should not be considered an obstacle to granting a patent for some transgenic plant or method of its production. Besides, it is highly unlikely that restrictions or prohibitions based on the new laws would be introduced in all the EU member states, considering the fact that GM plants are currently grown in some of those states.

The argument that there are local policies prohibiting the cultivation of some GM crops and that the exploitation of a GM plant would violate those policies or important values protected by them could be used in procedures before local patent offices. The patent office would then have to cope with the local legal situation and issues of moral importance in the territory of a particular state. Such a belief should be opposed. Even though there may be some moral justification underlying the introduction of restrictions on growing certain GMOs, those arguments do not automatically render the exploitation of an invention immoral. This issue should be considered by the patent office on a case by case basis and yet it still seems dubious that an invention could be considered immoral, because its exploitation was prohibited based on socioeconomic factors or, e.g., town and country planning. Also, the exploitation of such an invention should not be considered immoral, because of the fact that GMOs or their patenting are unpopular in a particular state (see Tosun, 2014). As has been mentioned several times by the EPO (see e. g. decisions T 356/93 p. 15, T 315/03 p. 10.4), public opinion polls are not suitable for deciding on what is morally acceptable or not, as their results can be easily skewed. Besides, the opinion of the majority does not necessarily reflect what constitutes part of morality or "ordre public". To sum up, while it cannot be excluded that there may be attempts to prevent the granting or revoking patents on GM plants, based to some extent on the newly adopted

rectly, but focuses more on the scope of patent protection and does not discuss issues of moral matter. A possible situation, where case C-428/08 would apply to our considerations would have to include an attempt to patent a DNA sequence, whose sole function was in itself incompatible with morality or "ordre public". The patent would not be granted, since the scope of protection would be limited to that function, but morality or public order exception would preclude patent protection of that very function. Such a situation does not seem likely, however. 
GMO legislation, it would constitute a radical change of currently established approach to that matter, if the patent offices decided to do so.

A different type of issue should also be considered here. Instead of debating whether obtaining a patent for transgenic plants in Europe is still possible, one should perhaps estimate whether it is economically justifiable (see also Cantley, 2012). Obtaining a new GM plant requires serious investment both monetary, and in terms of time and human resources. Meeting the criteria for authorization is also quite costly and time consuming, given how thorough the safety requirements and the risk assessment procedures are. Also, obtaining and maintaining a patent can prove quite costly, if one considers not only the cost of procedures and patent protection fees but also the costs of representation, translation etc. (although this would constitute only a fraction of the earlier mentioned costs). Ultimately, the patent holder may still be unable to market their product legally in some of the member states, due to the local restrictions on the cultivation of GMOs. It can be argued that the new developments in terms of EU laws on GMOs, while not impacting directly upon their patentability, provide for a hostile environment for the exploitation of such inventions.

\section{Conclusions}

The recent developments of laws on the cultivation of GM crops allow member states to restrict the use of such crops for reasons other than ones connected with bio-safety. This new approach constitutes a departure from the earlier policies, based on the precautionary and case by case approaches. Under the new legislation, member states can prohibit the cultivation of whole groups of GMOs in their territories, based on the requirements of local policies or social and economic concerns. This radical change in the approach could hypothetically influence the patentability of GM plants or methods of their production. This, however, seems rather unlikely, given the way the European Patent Office interprets the exclusions from patentability that are based on the grounds of morality or "ordre public". The possibility cannot be excluded that there may be attempts to invoke local policies prohibiting the use of GMOs in individual countries on the grounds of a denial or revocation of patents before local patent offices. Such attempts should be met with opposition. The mere fact that the cultivation of a GM crop is prohibited by law should not mean that the invention cannot be exploited in a different way or that the cultivation of such a crop is to be considered immoral. The new laws make the already unfriendly legal environment surrounding GMOs in the EU quite hostile, rendering the economic viability of such undertakings as GMP development, patenting and marketing, questionable.

\section{References}

Cantley M. (2012) European attitudes on the regulation of modern biotechnology and their consequences. GM Crops \& Food: Biotech. Agricult. Food Chain 3(1): 40-47.

COMEST (2005) The Precautionary Principle. UNESCO: $54 \mathrm{pp}$.

Crespi R.S. (2000) An Analysis of Moral Issues Affecting Patenting Inventions in the Life Sciences: A European Perspective. Sci. Engin. Ethics 6: 157-180.

Davidson J. (2010) GM plants: Science, politics and EC regulations. Plant Sci. 178: 94-98.

Gadomski A.M., Zimny T. (2009) Application of IPK (Information, Preferences, Knowledge). Paradigm for the Modeling of precautionary Principle based Decision Making. Lect. Notes Comput. Sci. 5508: 319-327.

Hansen G. (2002) Patentierbarkeit gentechnologischer Erfindungen - Unter besonderer Berücksichtigung ethischer und rechtspolitischer Aspekte. HFR 2: 1-17.

James C. (2015) Global Status of Commercialized Biotech/GM Crops:2014, http:www.isaaa.org/resources/publications/ briefs/49/executivesummary/default.asp, accessed June, 2015.

Jansen van Rijssen F.W., Morris E.J., Eloff J.N. (2015) The precautionary principle: Making managerial decisions on GMOs is difficult. South Afr.J. Sci.111(3/4), \# 2013- 0255.

Nanda V.P., Pring G. (2013) International Environmental Law and Policy for the 21st Century. Martinus Nijhoff Publ. pp. xvi, 668.

Schatz U. (2000) Patents and Morality. [in:] Biotechnology, Patents and Morality. Ed. Sterckx S., Aldershot: Ashgate.

Sterckx S., Cockbain J. (2012) Exclusions from Patentability How Far Has the European Patent Office Eroded Boundaries? Cambridge University Press.

Tosun J. (2014) Agricultural Biotechnology in Central and Eastern Europe: Determinants of Cultivation Bans. Sociol. Ruralis 54(3): 362-381.

\section{Legal acts and other official documents}

Directive 2001/18/EC on the deliberate release into the environment of genetically modified organisms and repealing Council Directive 90/220/EEC. OJ L 2001.106.001

Directive 2015/412/EU, amending Directive 2001/18/EC as regards the possibility for the Member States to restrict or prohibit the cultivation of genetically modified organisms (GMOs) in their territory. OJ L 2015.68.001 
Directive 98/44/EC on the protection of biotechnological inventions. OJ L 1998.213.013

Regulation 1829/2003/EC on genetically modified food and feed. OJ L 2003.268.001.

Convention on the Grant of European Patents (European Patent Convention) of 5 October 1973 with latest revisions.

Prawo własności przemysłowej (Law on Industrial Property). Dz. U. 2001.49.508 with latest revisions.

Ustawa o zmianie ustawy o organizmach genetycznie zmodyfikowanych oraz niektórych innych ustaw (Act Revising the Act on Genetically Modified Organisms and Several Other Acts). Dz. U. 2015.277.

Ustawa o nasiennictwie (Act on Seed Production). Dz. U. 2012.1512.

Rozporządzenie Rady Ministrów w sprawie zakazu stosowania materiału siewnego odmian kukurydzy MON810 (Regulation of the Council of Ministers on the Prohibition of Usage of MON 810 Maize Sowing Material). Dz. U. 2013.39 with latest revisions.
Communication of the Commission on the use of the precautionary principle. (COM) 2001/1.

Recommendation on the guidelines for the development of national co-existence measures to avoid the unintended presence of GMOs in conventional and organic crop, 2010.

\section{Decisions and judgments}

Decision of the Technical Board of Appeals of the European Patent Office T 356/93 (Plant Cells)

Decision of the Technical Board of Appeals of the European Patent Office T 315/03 (Harvard oncomouse)

Decision of the Enlarged Board of Appeals of the European Patent Office G 2/06 (WARF/Stem cells)

Decision of the Technical Board of Appeals of the European Patent Office T 179/01 (Syngenta).

European Court of Justice Judgment in the case C-377/98

European Court of Justice Judgment in the case C-428/08

European Court of Justice Judgment in the case C-442/09

European Court of Justice Judgment in the case C-34/10 